\title{
Deteksi Penyakit pada Daun Kentang Menggunakan Pengolahan Citra dengan Metode Convolutional Neural Network
}

\author{
Detection of Potato Leaves Disease Using Image Processing \\ with Convolutional Neural Network Methods
}

\author{
Abdul Jalil Rozaqi*1, Andi Sunyoto ${ }^{2}$, Rudyanto Arief ${ }^{3}$ \\ ${ }_{1,2}$ Magister Teknik Informatika, Universitas Amikom Yogyakarta \\ E-mail: *1abdul.13@students.amikom.ac.id, ${ }^{2}$ andi@amikom.ac.id, ${ }^{3}$ rudy@amikom.ac.id
}

\begin{abstract}
Abstrak
Produk pertanian kentang menjadi sangat penting karena termasuk makanan utama bagi manusia. Kentang memiliki kandungan karbohidrat yang menjadikanya sebagai makanan utama. Dalam mengelola pertanian kentang ini tentu memiliki beberapa kendala diantaranya adalah penyakit yang menyerang pada daun kentang yang jika dibiarkan akan menghasilkan produksi yang buruk atau bahkan gagal panen. Late blight dan early blight adalah penyakit yang sering ditemui pada daun kentang. Penyakit ini memiliki gejala masing-masing sehingga para petani dapat melakukan pencegahan jika melihat gejala pada daun kentang, tetapi langkah ini memliki kelemahan yaitu proses identifikasi yang lama, dan jika penanganan pada penyakit daun ini sangat lambat akan mengakibatkan penambahan biaya perawatan. Dengan memanfaatkan teknologi yaitu berupa pengolahan citra digital maka hal ini bisa diatasi, jadi pada penelitian ini akan mengusulkan metode yang tepat dalam mendeteksi penyakit pada daun kentang. Klasifikasi akan dilakukan dengan tiga kelas berupa daun sehat, early blight, dan late blight menggunakan metode Deep Learning mengguanakan arsitektur Convolutional Neural Network (CNN). Hasil pada peneltian ini dianggap baik karena pada epoch ke 10 dengan batch size 20 menghasilkan training akurasi 95\% dan validation accuracy $94 \%$.
\end{abstract}

Kata Kunci-Penyakit daun kentang, late blight, early blight, identifikasi, CNN

\begin{abstract}
Potato agricultural products are essential because they are the leading food. Potatoes have carbohydrate content, which makes them the leading food for humans. But in carrying out this potato farming certainly has several obstacles, including the disease that attacks the potato leaves which if left unchecked will result in poor production or even crop failure. late blight and early blight are diseases that are often found in potato leaves. This disease has its own symptoms so that farmers can take precautions if they see symptoms on potato leaves, but this step has a weakness that is a long identification process, and if the handling of this leaf disease is very slow will result in additional maintenance costs. By utilizing technology in the form of digital image processing, this can be overcome, so this research will propose an appropriate method in detecting diseases in the leaves of potato plants. Classification will be carried out with three classes in the form of healthy leaves, early blight, and late blight using the Convolutional Neural Network (CNN) algorithm. The results of this research are considered good because on the 10th epoch with batch size 20 produces 95\% accuracy training and 94\% validation accuracy.
\end{abstract}

Keywords_-Potato leaf disease, late blight, early blight, identification, CNN 


\section{PENDAHULUAN}

\subsection{Latar Belakang}

Tanaman kentang sangat banyak manfaatnya bagi kehidupan manusia. Kentang adalah salah satu makanan utama karena mengandung karbohidrat. Tidak dapat dipungkiri tanaman kentang juga pasti memiliki penyakit, jika penyakit tanaman ini dibiarkan akan meningkatkan penurunan produksi pangan, maka perlunya pendeteksian penyakit pada tanaman pada waktu yang tepat supaya dapat mengendalikan dan mencegah secara efektif untuk penyakit tanaman [1]. Penyakit pada tanaman kentang yang paling banyak ditemui adalah busuk daun (late blight), dan juga ada penyakit bercak kering daun (early blight). Tempat dingin dan lembab adalah salah satu faktor penyakit busuk daun berkembang [2].

Penyakit busuk daun (late blight) akan timbul pada masa pertumbuhan tanaman antara minggu ke 5 dan minggu ke 6, gejala awal penyakit busuk daun ini adalah adanya bercak basah di bagian tepi daun dan bisa juga pada bagian tengah. Kemudian bercak ini akan melebar dan warna daun berubah menjadi coklat/abu-abu. Sedangkan gejala penyakit bercak kering (early blight) ditadai dengan bercak kering berupa lingkaran berwarna coklat di bagian bawah daun [3]. Penyakit pada daun kentang ini jika dibiarkan akan menular kebagian tangkai dan akan menurunkan hasil panen bahkan dapat menyebabkan gagal panen. Dengan melihat gejala yang terjadi pada tanaman kentang ini para petani dapat segera menangani masalah penyakit daun busuk. Namun dalam proses melihat gejala yang ada memiliki beberapa kendala dikarenakan tidak semua petani memiki pengetahun tentang cara pengenalan gejala penyakit ini secara menyeluruh.

Dalam menangani masalah pada penyakit pada daun kentang ini telah banyak dilakukan, tidak hanya didalam bidang pertanian saja tetapi pada bidang teknologi pun turut ikut andil, salah satunya adalah pemanfaatan bidang informatika dalam mengidentifikasi penyakit yang ada pada tanaman kentang dengan menggunakan image processing atau biasa disebut pengolahan citra digital. Pemanfaatan image processing dalam melakukan identifikasi dapat membantu para pengelola pertanian untuk memberikan penanganan secara efektif dan efisien pada tanaman yang tidak sehat atau tidak normal. Dengan berkembangnya teknologi saat ini telah banyak penelitian yang mengembangkan pengolahan citra digital dalam bidang pertanian baik untuk mengidentfikasi penyakit ataupun mengidentifikasi hasil produksi pertanian. Salah satu pemanfaatan penelitian citra digital dalam menyelesaikan masalah pada penelitian ini adalah untuk identifikasi penyakit pada daun tanaman kentang.

Penelitian ini bertujuan untuk membuat sistem yang dapat membantu para petani atau pengelola pertanian dalam mengidentifikasi penyakit pada daun kentang dengan memanfaatkan data gambar daun kentang. Identifikasi daun pada tanaman kentang ini dibagi menjadi tiga bagian yaitu tanaman kentang dengan daun sehat atau normal, late bligt, dan early blight. Maka pada penelitian ini akan melakukan identifikasi ini menggunakan algoritma Convolutional Neural Network (CNN) yang merupakan salah satu dari metode Deep Learning. Data yang digunakan berupa data penyakit pada daun tanaman kentang didapat dari website kaggle dengan nama PlantVillage [4].

\subsection{Penelitian Terdahulu}

Penelitian sebelumnya banyak yang telah melakukan uji coba dalam mengolah data citra digital baik dalam nenetukan kualitas hasil tanaman dan juga mendeteksi penyakit pada tanaman.

Islam. M pada penelitiannya "Detection of Potato Diseases Using Image Segmentation and Multiclass Support Vector Machine" menggunakan metode Support Vector Machine (SVM) untuk mendeteksi penyakit pada daun kentang dengan jumlah data gambar daun yang digunakan 200 data daun yang sakit dan 100 daun yang normal atau sehat. Proses pada penelitian ini adalah dengan melakukan segmentasi citra untuk menampilkan penyakit pada daun saja tanpa menampilkan background dan daun yang normal dalam artian warna hijau daun, kemudian 
gambar daun akan di ekstrak tekstur nya menggunakan Gray Level Co-occurrence Matrix (GLCM). Hasil dari penelitian ini meiliki akurasi sebesar 95\% [5].

Prakash dalam penelitianya melakukan segmentasi untuk menghilangkan background pada gambar daun dengan menggunakan K-Means clustering, dan juga melakukan ekstraksi tekstur daun menggunakan fitur Gray Level Co-Occurence Matrix (GLCM) supaya hanya menampilkan daun yang tidak berwarna hijau atau yang tidak normal. Pada tahap terakhir melakukan klasifikasi dengan menggunakan algoritma Support Vector Machine (SVM) dan menghasilkan akurasi 90\% dari data gambar yang digunakan sebanyak 60 gambar [6].

Astiningrum pada penelitianya melakukan deteksi daun berpenyakit pada tanaman tomat. Pada proses dalam melakukan identifikasi penyakit daun pada tanaman tomat peneliti melakukan ekstraksi warna dengan fitur RGB dan kemudian melakukan ekstraksi tekstur dengan fitur GLCM. Selanjutnya dilakukan klasifikasi data dengan menggunakan algoritma K-Nearest Neighbor (K-NN) dan menghasilkan tingkat akurasi sebesar 92,89\% pada k=1 dengan data yang digunakan dalam penelitian ini berjumlah 750 citra daun dengan pembagian data training 600 citra dan data testing 150 citra [7].

Dalam melakukan klasifikasi tanaman pada citra yang memiliki resolusi tinggi menggunakan Convolutional Neural Network (CNN) memiliki hasil akurasi 93\%. Peneliti menerangkan bahwa metode CNN merupakan metode deep learning yang mampu mengenali objek dengan proses pembelajaran secara mandiri. Dalam penelitianya bertujuan untuk melakuakn identifikasi jenis tanaman dengan menggunakan foto dari lima jenis tanaman berupa tanaman padi, bawang merah, kelapa, pisang, dan cabai yang mana dari masing-masing jenis terdapat 100 foto. Peneliti juga menerangkan bahwa jumlah data training yang digunakan dalam pengklasifikasian tanaman dengan menggunakan Convolutional Neural Network (CNN) mempengaruhi hasil akurasi [8].

Penelitian sebelumnya dilakukan klasifikasi dengan 6 kelas berupa healthy, late blight, yellow curved, tomato mosaic, bacterial spot, septorial leaf spot. Metode yang digunakan untuk melakukan klasifikasi adalah Deep Learning dengan menggunakan Convolutional Neural Network (CNN). Pada penelitian ini mendapatkan hasil akurasi terbaik pada dengan menjalankan 30 epochs dengan hasil training accuracy 92.61\% dan validation accuracy menghasilkan 96.55\% [9]. Metode Deep Learning mampu melakukan klasifikasi dan ekstraksi citra dengan proses pembelajaran data yang dimiliki secara mandiri, sehingga dengan Deep Learning ini proses klasifikasi dan ektraksi fitur dilakukan bersamaan pada satu proses, berbeda dengan klasifikasi yang dilakukan dengan menggunakan metode SVM dan K-NN pada penelitian sebelumnya dimana sebelum proses klasifikasi ada proses ekstraksi fitur [10].

Dari uraian penelitian yang telah dilakukan dalam melakukan identifikasi penyakit tanaman dengan menggunakan dataset gambar daun, dapat dilihat ada yang menggunakan algoritma Support Vector Machine (SVM) dengan tambahan melakukan proses ektraksi fitur GLCM untuk ekstraksi tekstur daun dan fitur RGB untuk ektraksi warna daun menjadi grayscale. Pada penelitian yang lainya seperti yang dilakukan Mim adalah mendeteksi penyakit pada daun tomat dengan Convolutional Neural Network (CNN) dan menghasilkan akurasi yang baik. Pada penelitian ini dalam membantu para petani untuk menentukan daun yang berpenyakit maka akan dilakukan identifikasi penyakit pada daun tanaman kentang dengan menggunakan metode Deep Learning dengan arsitektur Convolutional Neural Network CNN sehingga dalam proses identifikasi tidak bergantung pada proses ektraksi fitur secara terpisah karena dalam layer CNN pada proses konvolusi dan pooling dilakukan ektraksi fitur pada citra daun tanaman kentang yang digunakan.

\section{METODE PENELITIAN}

Pada penelitian ini ada beberpa tahapan penyelesaian dalam melakukan klasifikasi penyakit daun pada tanaman kentang seperti yang ditampilkan pada Gambar 1. 


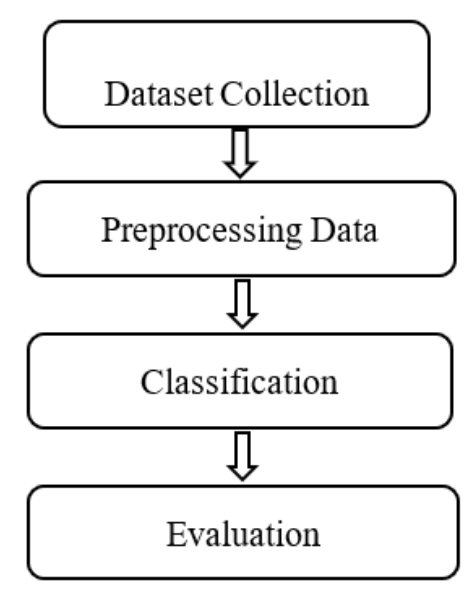

Gambar 1. Kerangka Penelitian

Gambar 1 merupakan kerangka penelitian yang dilakukan dalam melakukan identifikasi penyakit pada daun tanaman kentang. Dalam kerangka penelitian ini terdapat empat tahapan dimulai dari dataset collection (pengumpulan data), preprocessing data (persiapan data sebelum di proses), kemudian tahap classification pada citra daun tanaman kentang yang digunakan dan yang terakhir adalah tahap evalutian yang berfungsi untuk melakukan evaluasi terhadap metode klasifikasi yang telah dilakukan. Penjelesan dari tiap-tiap tahap pada kerangka penelitian dalam Gambar 1 akan dijelaskan lebih lanjut sebagai berikut:

\subsection{Dataset Collection}

Dataset Collection merupakan tahapan pengumpulan data yang akan digunkan pada penelitian ini dalam menentukan penyakit daun pada tanaman kentang. Karena pada penelitian ini bersifat supervised learning dimana pada proses klasifikasi menggunakan data yang sudah ada yang memiliki label dari masing-masing kelas [11], maka data daun tanaman kentang yang digunakan memiliki label atau kelas yang dibagi menjadi tiga yaitu late blight, early blight, dan daun sehat atau normal.

Dataset yang digunakan pada penelitian ini berupa gambar daun tanaman kentang yang dibagi menjadi tiga kelas yaitu late blight yang ditampilkan pada Gambar 2 (a), early blight yang ditampilkan pada Gambar 2 (b), dan daun sehat yang ditampilkan pada Gambar 2 (c). Dataset ini didapatkan dari website Kaggle dengan nama "PlantVillage Dataset" yang diunggah oleh Tairu Oluwafemi Emmanuel dan perubahan yang terakhir dilakukan pada oktober 2018 [4].

Tabel 1. Detail Dataset

\begin{tabular}{|c|c|c|}
\hline Sampel & Jumlah data & Sumber Data \\
\hline Late Blight & 500 & \multirow{4}{*}{$\begin{array}{c}\text { Kaggle } \\
\text { (PlantVillage) }\end{array}$} \\
\hline Early Blight & 500 & \\
\hline Daun Sehat & 152 & \\
\hline Total & 1152 & \\
\hline
\end{tabular}

Detail data ditampilkan pada Tabel 1 dimana total dari keseluruhan data citra daun tanaman kentang yang digunakan berjumlah 1152 dengan rincian jumlah data yang digunakan adalah 500 data late blight, 500 data early blight dan 152 data daun sehat atau normal.

Semua gambar yang digunakan dalam penelitian ini akan dirubah ukuranya menjadi 150x150 untuk mempercepat pemrosesan. Gambar 2 adalah contoh citra dari masing-masing kelas data yang digunakan. 


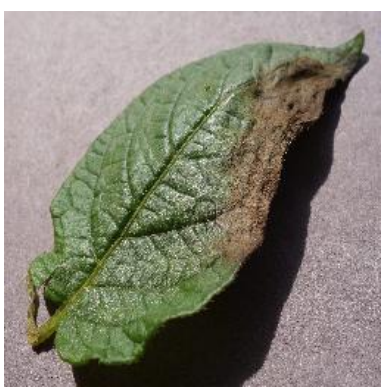

(a)

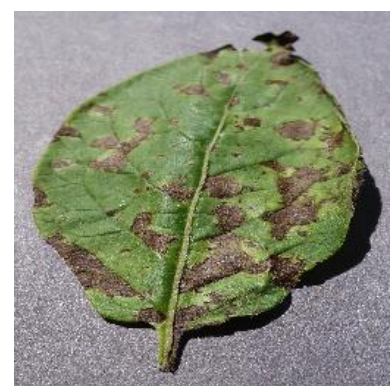

(b)

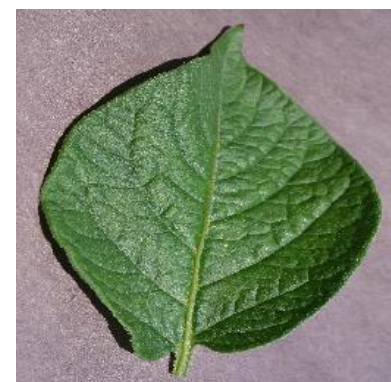

(c)

Gambar 2 (a) Late blight (b) Early blight (c) Daun sehat

Pada Gambar 2 (a) adalah gambar pada tanaman kentang dengan penyakit late blight atau busuk daun, pada bagian pinggir daun berubah menjadi warna kecoklatan dan ini akan melebar dengan berjalanya waktu. Gambar 2 (b) adalah gambar daun pada tanaman kentang yang memiliki penyakit early blight atau bercak daun, dapat dilihat pada tengah bagian daun terdapat bercak-bercak kecoklatan yang merusak daun. Gambar 2 (c) adalah gambar daun kentang yang tidak memiliki penyakit atau daun sehat.

\subsection{Preprocessing Data}

Preprocessing data merupakan tahap persiapan sebelum data diolah dan digunakan untuk melakukan klasifikasi. Pada tahap ini persiapan data yang dilakukan adalah menentukan jumlah data yang digunakan yaitu 1152 gambar dari 3 kelas, pembagian kelasnya adalah late blight, early blight dan daun sehat.

Tabel 2. Pembagian Dataset

\begin{tabular}{lcc}
\hline \multicolumn{1}{c}{ Dataset } & $\begin{array}{c}\text { Data Training } \\
\mathbf{8 0 \%}\end{array}$ & $\begin{array}{c}\text { Data Testing } \\
\mathbf{2 0 \%}\end{array}$ \\
\hline Late Blight & 400 & 100 \\
\hline Early Blight & 400 & 100 \\
\hline Daun Sehat & 122 & 30 \\
\hline Total & 922 & 230 \\
\hline
\end{tabular}

Tahap persiapan data selanjutnya adalah membagi data yang digunakan, pada Tabel 2 adalah detail dari pembagian setiap data dari masing-masing kelas yang digunakan dibagi menjadi data training dan data testing dengan pembagian data $80 \%$ dan $20 \%$. Dari pembagian data ini maka pada data training terdapat 922 data citra yang digunakan dengan rincian 400 data citra daun late blight, 400 data citra daun early blight, dan 122 data daun sehat atau normal. Pada data testing terdapat 230 data citra yang digunakan dengan rincian 100 data citra daun late blight, 100 data citra early blight, dan 30 data citra daun sehat atau normal. Gambar daun yang digunakan terlebih dahulu akan dirubah ukuranya menjadi 150x150 untuk mempercepat pemrosesan klasifikasi.

\subsection{Classification}

Pada Tahap selanjutnya adalah melakukan klasifikasi gambar dengan menggunakan metode Convolutional Neural Network (CNN). Algoritma CNN termasuk dalam metode supervised learning dimana identifikasi suatu gambar dengan melatih data gambar yang sudah ada dan menargetkan variabel gambar. 
Convolutional layer CNN membantu jaringan saraf pada CNN mengenali daun kentang berdasarkan atribut-atribut yang dimmilikianya. Jaringan saraf dapat mengenali gambar daun kentang berdasarkan piksel-piksel yang ada didalam gambar.

Convolutional menggunakan filter untuk mengenali atribut-atribut yang ada pada gambar daun. Pada proses konvolusi ini akan dilakukan perkalian matriks terhadap filter dan area citra daun. Seperti yang ditunjukan pada Gambar 3 dapat dilihat bahwa proses konvolusi ini mengalikan piksel pada gambar dengan piksel filter.
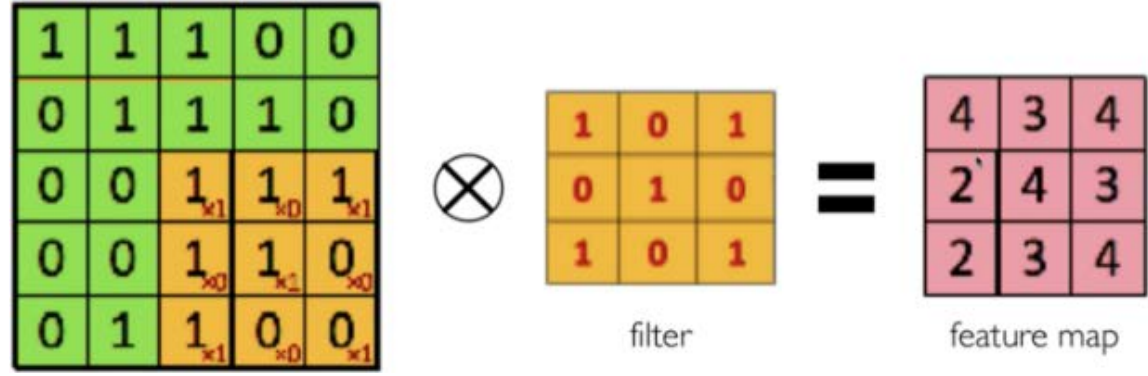

Gambar 3. Proses konvolusi

Setelah dilakukan konvolusi selanjutnya melakukan max pooling. Pooling disini berarti proses yang dilakukan untuk mendapatkan gambar dengan piksel yang lebih kecil tetapi tetap dengan mempertahankan informasi yang ada pada gambar.

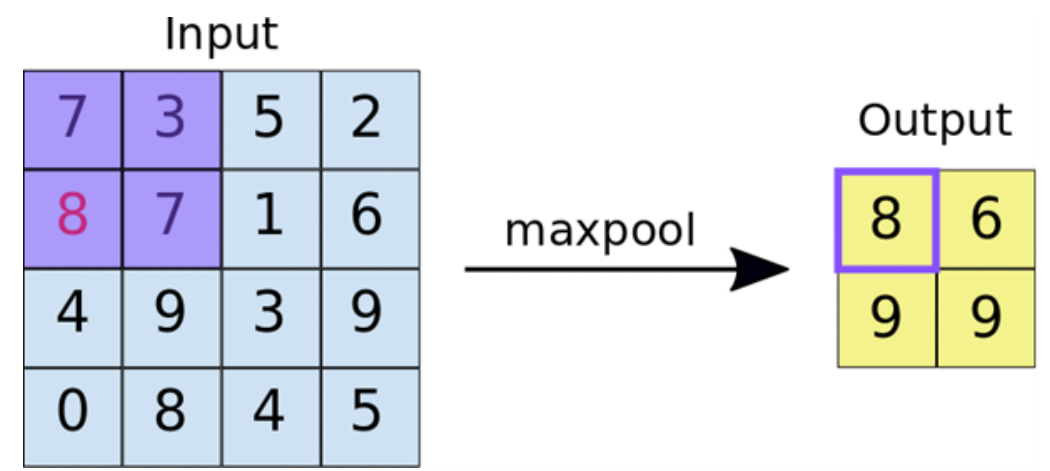

Gambar 4. Proses pooling pada CNN

Pooling process dapat dilihat pada Gambar 4 dimana pada area gambar dengan luas piksel tertentu akan dilakukan pooling yaitu dengan memilih salah satu piksel yang paling tinggi. Proses ini sangat membantu karena akan mengurani besar ukuran dari setiap gambar dan akan dapat mempercepat proses klasifikasi.

Pada penelitian ini akan menggunakan citra dengan ukuran 150x150x3 yang mana maksudnya disini adalah gambar ukuran 150x150 dan citra ini memiliki 3 channel yaitu red, green, and blue (RGB). Citra daun ini akan dilakkuan konvolusi dulu dengan filter, kemudian akan dilakukan pooling utnuk mengecilkan resolusi citra dengan tetap mempertahankan kualitas citra, pooling yang digunakan adalah maxpooling pada citra masukan.

Proses selanjutnya fully connected layer, dimana pada proses ini adalah melakukan flatten, maksud flatten disini adalah mengubah feature map hasil dari pooling menjadi bentuk vektor. Untuk lebih jelasnya ditampilkan pada Gambar 5 arsitektur dari algoritma CNN. 


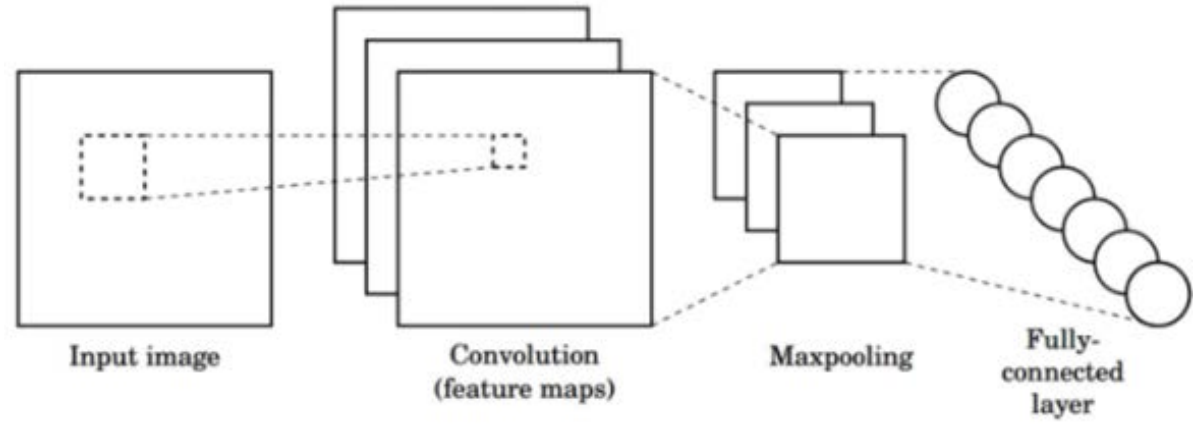

Gambar 5. Arsitektur pada Convolutional Neural Network

Gambar 5 menjelaskan image input (citra masukan) akan dilakukan proses konvolusi untuk mendapatkan feature maps dalam artian mendeteksi atribut atau fitur yang dimiliki oleh citra. Kemudian hasil dari konvolusi ini dilakukan max pooling untuk merubah ukuran citra menjadi lebih kecil sehingga proses pengklasifikasian data akan lebih cepat, terakhir hasil dari max pooling dimasukkan pada proses fully connected layer.

Pada penelitian ini model yang diusulkan untuk arsitektur CNN dalam mengidentifikasi penyakit pada daun kentang ditampilkan pada Tabel 3.

Tabel 3. Model Convolutional Neural Network yang diusulkan

\begin{tabular}{llc}
\hline \multicolumn{1}{c}{ Layer } & \multicolumn{1}{c}{ Output Shape } & Param \\
\hline conv2d_4 (Conv2D) & (None, 148, 148, 32) & 896 \\
\hline max_pooling2d_4 (MaxPooling2 & (None, 74, 74, 32) & 0 \\
\hline conv2d_5 (Conv2D) & (None, 72, 72, 64) & 18496 \\
\hline max_pooling2d_5 (MaxPooling2 & (None, 36, 36, 64) & 0 \\
\hline conv2d_6 (Conv2D) & (None, 34, 34, 128) & 73856 \\
\hline max_pooling2d_6 (MaxPooling2 & (None, 17, 17, 128) & 0 \\
\hline conv2d_7 (Conv2D) & (None, 15, 15, 256) & 295168 \\
\hline max_pooling2d_7 (MaxPooling2 & (None, 7, 7, 256) & 0 \\
\hline flatten_1 (Flatten) & (None, 12544) & 0 \\
\hline dense_2 (Dense) & (None, 512) & 6423040 \\
\hline dense_3 (Dense) & (None, 3) & 1539 \\
\hline Total params: 6,812,995 & & \\
Trainable params: 6,812,995 & & \\
Non-trainable params: 0 & & \\
\hline
\end{tabular}

Pada Tabel 3 merupakan arsitektur CNN dari metode Deep Learning yang diuslkan pada penelitian ini, bisa kita lihat pada arsitektur ini menggunakan empat lapisan layer konvolusi dimana dipadukan dengan max pooling, kemudian hasil dari proses konvolusi dan pooling ini dilakukan flatten untuk mengubah feature map hasil dari pooling menjadi bentuk vektor.

\section{HASIL DAN PEMBAHASAN}

Epoch merupakan proses training pada neural network sampai kembali lagi pada tahap awal dalam satu putaran ketika seluruh dataset melalui proses ini. Pada pelatihan data dengan model neural network jika hanya menggunakan satu epoch saja maka ini akan terlalu besar dan mmberatkan proses pelatihan pada dataset, karena data yang digunakanan cukup banyak maka dibutuhkan pembagian data rate per batch (batch size). Pada penelitian ini ada 20 batch size dan untuk menentukkan jumlah epoch nya maka peneliti menyesuaikan jumlah batch size dengan jumlah sampel yang dipakai. 
Citec Journal, Vol. 8, No. 1, Januari 2021

ISSN: 2354-5771

Pada proses klasifikasi ini dilakukan dengan jumlah data 1152 yang telah dibagi 80\% untuk data training dan $20 \%$ untuk data testing dimana dengan rincian 922 data citra daun tanaman kentang untuk data training dan 230 data citra daun tanaman kentang untuk data testing, kemudian menggunakan 20 batch size dan 40 steps per epoch untuk data training dan 11 steps per epoch untuk data testing.

Langkah selanjurnya adalah melakukan pelatihan pada citra daun kentang yang sudah dibagi dengan fit model. Tabel 4 merupakan hasil dari fit model, dapat dilihat dari epoch 1 ke epoch 10 nilai akurasi pada data train dan nilai akurasi pada data test mengalami peningkatan.

Tabel 4. Hasil dari fit model

\begin{tabular}{crrrl}
\hline \multirow{2}{*}{ Epoch } & \multicolumn{2}{c}{ Data Training } & \multicolumn{2}{c}{ Data Testing } \\
\cline { 2 - 5 } & Acc & Loss & Val Acc & Val Loss \\
\hline 1 & 0.4783 & 0.6146 & 0.7227 & 0.5024 \\
\hline 2 & 0.7161 & 0.4057 & 0.7773 & 0.3737 \\
\hline 3 & 0.7688 & 0.3364 & 0.8364 & 0.2621 \\
\hline 4 & 0.8645 & 0.2260 & 0.7773 & 0.3855 \\
\hline 5 & 0.8939 & 0.1752 & 0.9045 & 0.1621 \\
\hline 6 & 0.9399 & 0.1051 & 0.9091 & 0.1294 \\
\hline 7 & 0.9220 & 0.1374 & 0.8682 & 0.2083 \\
\hline 8 & 0.9527 & 0.0844 & 0.9273 & 0.0946 \\
\hline 9 & 0.9399 & 0.1018 & 0.9227 & 0.1208 \\
\hline 10 & 0.9527 & 0.0711 & 0.9409 & 0.1086 \\
\hline
\end{tabular}

Dapat dilihat pada Tabel 4 hasil dari pada epoch pertama menampilkan nilai akurasi 0,4783 dengan nilai loss yang diperoleh yaitu 0,6146 , selanjutnya pada epoch kedua menampilkan nilai akurasi 0,7161 dengan nilai loss yang diperoleh yaitu 0,4057, kemudian pada pada epoch ketiga menampilkan nilai akurasi 0,7688 dengan nilai loss yang diperoleh yaitu 0,2260 dan seterusnya hingga epoch ke 10 menampilkan nilai akurasi 0,9527 dengan nilai loss yang diperoleh 0,0711. Sedangkan pada data testing didapat nilai akurasi pada epoch pertama adalah 0,7227 dengan nilai loss yang diperoleh 0,5024 selanjutnya pada epoch kedua menampilkan nilai akurasi 0,7773 dengan nilai loss yang diperoleh yaitu 0,3737, kemudian pada pada epoch ketiga menampilkan nilai akurasi 0,8364 dengan nilai loss yang diperoleh yaitu 0,2621 dan seterusnya hingga epoch ke 10 menampilkan nilai akurasi 0,9409 dengan nilai loss yang diperoleh adalah 0,1086 .

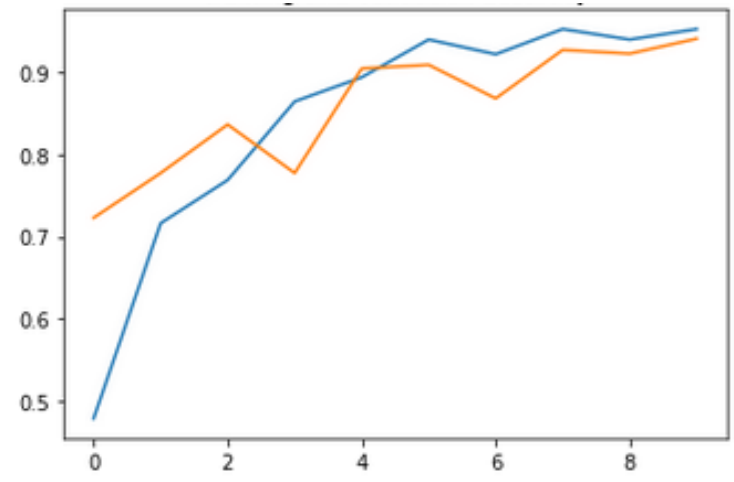

Gambar 6. Nilai Akurasi dari data training dan data testing 


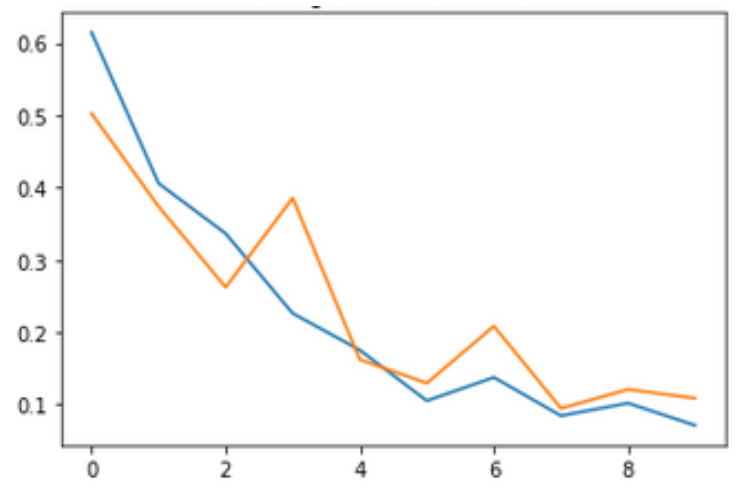

Gambar 7. Nilai loss dari data training dan data testing

Pada Gambar 6 dan Gambar 7 adalah grafik dari akurasi dan loss yang dihasilkan dari klasifikasi daun tanaman kentang menggunakan arsitektur CNN yang diusulkan. Garis pertama pada gambar 6 dan garis kedua pada gambar 7 menunjukkan data testing. Sedangkan, garis kedua pada gambar 6 dan garis pertama pada gambar 7 menunjukkan data training.

Dapat dilihat pada Gambar 6 untuk data training dan testing nilai akurasinya naik terus. Kemudian dapat dilihat juga pada Gambar 7 untuk data training dan testing nilai loss turun terus. Grafik accuracy dan loss menunjukkan terdapat korelasi dari hubungan antara nilai akurasi dari data training dan data testing, korelasi ini menunjukkan korelasi yang positif karena memiliki hubungan yang searah.

\section{KESIMPULAN}

Dari penelitian ini dapat ditarik kesimpulan berdasarkan implementasi model yang dilakukan dan testing yang dijalankan terhadap data daun kentang memiliki hasil yang bagus dengan pembagian dataset 80\% dan 20\% dan gambar yang digunakan ukuranya dirubah 150x150. Pada epoch ke 10 dengan batch_size 20 dengan total data training 922 gambar dan data testing 230 gambar menghasilkan nilai akurasi 95\% dan untuk akurasi validasi menghasilkan 94\%.

\section{SARAN}

Pada penelitian ini memiliki beberapa saran untuk penelitian selanjutnya berupa penambahan data yang digunakan pada data daun sehat sehingga memiliki total data yang sama antara data daun sehat, late blight dan early blight.

\section{DAFTAR PUSTAKA}

[1] Chen, J., Chen, J., Zhang, D., Sun, Y., Nanehkaran, Y. A., 2020, Using deep transfer learning for image-based plant disease identification, Computers and Electronics in Agriculture, Vol. 173, Hal. 105393, doi: 10.1016/j.compag.2020.105393.

[2] Fitriana, A., Hakim, L., Marlina, 2019, Efektivitas Cendawan Endofit Asal Akar Tanaman Kentang Dalam Media Kompos Kulit Kopi Untuk Menekan Perkembangan Penyakit Hawar Daun Kentang (Phytophtora Infestans), Jurnal Agrista, No. 1, Vol. 23, Hal. 9-14

[3] Susetyo, H. P., 2017, Penyakit Busuk Daun Kentang, Website Direktorat Jenderal Hortikultura Kementrian Pertanian, http://hortikultura.pertanian.go.id/?p=2025.

[4] Emmanuel, T. TlantVillage $\quad$ O., Dataset, Kaggle, https://www.kaggle.com/emmarex/plantdisease, diakses pada 24 Juli 2020 
[5] Islam, M., Dinh, A., Wahid, K., Bhowmik, P., 2017, Detection of Potato Diseases using Image Segmentation and Multiclass Support Vector Machine, Conference: 2017 IEEE 30th Canadian Conference on Electrical and Computer Engineering (CCECE), Canada, 30 April - 3 Mei, doi: 10.1109/CCECE.2017.7946594.

[6] Prakash R, M., Saraswathy, G. P., Ramalakshmi, G., Mangaleswari, K. H., Kaviya, T., 2017, Detection of leaf diseases and classification using digital image processing, Conference: 2017 4th International Conference on Innovations in Information, Embedded and Communication Systems, Tamilnadu - India, 17 - 18 Maret.

[7] Astiningrum, M., Arhandi, P. P., Ariditya, N. A., 2017, Identifikasi Penyakit pada Daun Tomat Berdasarkan Fitur Warna dan Tekstur, TeknoSains, No. 2, Vol. 6131, Hal. 113-123.

[8] Arrofiqoh, E. N., Harintaka, H., 2018, Implementasi Metode Convolutional Neural Network Untuk Klasifikasi Tanaman Pada Citra Resolusi Tinggi, Jurnal Geomatika, No. 2, Vol. 24, Hal. 61, doi: 10.24895/jig.2018.24-2.810.

[9] Mim, T. T., Sheikh, M. H., Shampa, R. A., Reza, M. S., Islam, M. S., 2019, Leaves Diseases Detection of Tomato Using Image Processing, 2019 8th International Conference System Modeling and Advancement in Research Trends (SMART), Moradabad - India, 22 - 23 Nov.

[10] Maulana, F. F., Rochmawati, N., 2019, Klasifikasi Citra Buah Menggunakan Convolutional Neural Network, Journal of Informatics and Computer Science (JINACS), No. 2, Vol. 01, Hal. 104-108.

[11] Ilahiyah, S., Nilogiri, A., 2018, Implementasi Deep Learning Pada Identifikasi Jenis Tumbuhan Berdasarkan Citra Daun Menggunakan Convolutional Neural Network, JUSTINDO Jurnal, No. 2, Vol. 3, Hal. 49-56, doi: 10.32528/JUSTINDO.V3I2.2254. 